\title{
Features of uterine blood flow in adolescents with abnormal uterine bleeding of puberty
}

\section{Irina Tuchkina, Lyudmila Vygovskaya, Anastasia Novikova}

Department of Obstetrics, Gynecology and Pediatric Gynecology, Kharkiv National Medical University, Kharkiv, Ukraine

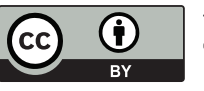

This work is licensed under a Creative Commons Attribution 4.0 International License
Intive

Received: 2019-03-23

Accepted: 2019-09-08

UDC: $618.14-005-053.6-073.432 .19$

\section{J Clin Med Kaz 2019; 4(54):21-24}

Corresponding author: Anastasiya Novikova, Department of Obstetrics, Gynecology and Pediatric Gynecology, Kharkiv National Medical University. Postal address: ap. 142, 11 Sukhumskaya Street, Kharkiv 61145, Ukraine. Tel.: +38 0503235292

Email: anastasiyanovikova@yahoo.com

\section{ABSTRACT}

The aim of this study was to study the ultrasound characteristics of the pelvic organs and the characteristics of uterine blood flow in adolescents with abnormal uterine bleeding during puberty.

Methods: Investigate 93 adolescent girls with abnormal uterine bleeding during puberty (AUBDP), aged 11 to 18 years (mean age was $14.5 \pm 3.5$ years). Patients with AUBDP were divided into 2 clinical groups: I group consisted of 44 patients 11-14 years old, group II - 49 adolescent girls 15-17 years old. The control group included 25 person of the same age without menstrual disorders. The frequency of relapses of AMKPP in group I was 20,4\%, in group II - 28,5\%.

Ultrasound and Doppler study was performed using an ultrasound scanner "Siemens" (Germany), using a transabdominal sensor (3.5 MHz) and a transvaginal sensor $(6.5-7 \mathrm{MHz})$ in adolescents who have sex.

The conditional of blood flow in the uterine and spiral arteries was performed using Doppler study. The indices of vascular resistance in both the uterine and spiral arteries, the index resistance (IR), the pulsation index (PI), and the systolic-diastolic ratio (S/D) were calculated.

Results: The study revealed hemodynamic changes in blood flow in girls with AUBDP. In this connection, the described changes in the parameters of blood flow in a. uterinae and a. radialis can serve as an additional diagnostic criterion for determining the risk of uterine bleeding during puberty.

Conclusion: Based on the study, ultrasound and Dopplerometric features of the pelvic organs in adolescent girls with AUBDP were found, which were characterized by an increase in the size of the uterus, heterogeneous endometrial echostructure, an increase in the size of the ovaries, an increase in systolic and diastolic blood flow rates, and vascular resistance indices in a. uterinae and a. radialis

Key words: puberty, abnormal uterine bleeding, blood flow characteristics

\section{ЖЫНЫСТЫҚ ЖЕТІЛУ КЕЗЕНІНДЕГІ ЖАТЫРДЫН АНОМАЛДЫ ҚАН КЕТУІ БАР ЖАСӨСПІРІМДЕРДЕ ЖАТЫРДАН ҚАН АҒУ ЕРЕКШЕЛІГІ \\ Тучкина И.А., Выговская Л.А., Новикова А.А. \\ Акушерлік, гинекология және балалар гинекологиясы кафедрасы, Харьков ұлттық медицина университеті, Харьков, Украина}

\section{ТҰЖЫРЫМДАМА}

Бұл жұмыстың мақсаты жыныстық жетілу кезеңіндегі жатырдан аномалды қан кетуімен жасөспірімдерде жамбас мүшелерінің ультрадыбыстық сипаттамаларын және жатырдың қан ағымының ерекшеліктерін зерттеу болды.

Әдістері: жыныстық жетілу кезеңіндегі жатырдан аномалды қан кету ауруына шалдыққан 93 жасөспірім-қыздар тексерілді, 11 жастан 18 жасқа дейін (орташа жасы 14.5 土 3,5 жас) құрады. Жатырдан тыс қан кету ауруына шалдыққан пациенттер 2 клиникалық топқа бөлінді: топты 11-14 жастағы 44 пациент құраса, II топты - 15-17 жастағы 49 жасөспірім қыздар құрады. Бақылау тобына етеккір қызметі бұзылмаған 25 құрдас қыздар кірді. Жыныстық жетілу кезеңіндегі жатырдан аномалды қан кетудің қайталану жиілігі I топта 20,4\% құрады, II топта - 28,5\%.

Ультрадыбыстықжәне доплерометриялық зерттеулер «Siemens» (Германия) ультрадыбыстық сканерінің көмегіментрансабдоминальды түрлендіргішті (3,5 МГц) және жыныстық қатынастағы жасөспірімдерде трансвагинальды түрлендіргішті (6,5-7 МГц) қолдана отырып жүргізілді.

Жатыр мен спиральды артериялардағы қан ағымының жағдайы доплерометриялық зерттеулердің көмегімен жасалды. Жатыр мен спиральды артериялардың тамырлы тұрақтылық көрсеткіштері, қарсылық индексі (IR), пульсация индексі (PI), систолалық-диастолалық қатынас (S / D) есептелінді.

Нәтижелері: Зерттеуде жыныстық жетілу кезеңіндегі жатырдан аномалды қан кетуі бар қыздарда қан ағымындағы гемодинамикалық өзгерістер анықталды. Осыған байланысты а. uterinae және a. radialis a. ішіндегі қан ағымының параметрлеріндегі сипатталған өзгерістер жыныстық жетілуден кейінгі кезеңде жатырдың қан кету қаупін анықтау үшін қосымша диагностикалық критерий бола алады. 
қорытындылар: Жүргізілген зерттеу нәтижелері бойынша жыныстық жетілу кезеңіндегі жатырдан аномалды қан кетуі бар жасөспірім қыздарда жамбас мүшелерінің ультрадыбыстық және доплерометриялық ерекшеліктері анықталды, олар жатыр мөлшерінің ұлғаюымен, эндометрияның гетерогенді эхоструктурасымен, аналық без мөлшерінің ұлғаюымен, систолалық және диастолалық қан ағымының жылдамдығымен, сондай-ақ а. uterinae және a. Radialis ішіндегі тамырлардағы қарсылықтың жоғарылауымен сипатталды.

Негізгі сөздер: жыныстық жетілу кезеңі, жатырдан аномалды қан ағыны, қан ағынының ерекшеліктері

\section{ОСОБЕННОСТИ МАТОЧНОГО КРОВОТОКА У ПОДРОСТКОВ С АНОМАЛЬНЫМИ МАТОЧНЫМИ КРОВОТЕЧЕНИЯМИ ПУБЕРТАТНОГО ПЕРИОДА}

Тучкина И.А., Выговская Л.А., Новикова А.А.

Кафедра акушерства, гинекологии и детской гинекологии, Харьковский национальный медицинский университет, Харьков, Украина

\section{PЕЗЮME}

Целью настоящей работы было изучение ультразвуковых характеристик органов малого таза и особенностей маточного кровотока у подростков с аномальными маточными кровотечениями пубертатного периода.

Методы: Обследовано 93 девочки-подростка с аномальными маточными кровотечениями пубертатного периода (АМкПП), в возрасте от 11 до 18 лет (средний возраст составил $14.5 \pm 3,5$ лет). Пациентки с АМКПП были разделены на 2 клинические группы: І группу составили 44 пациентки 11-14 лет, II группу - 49 девочек-подростков 15-17 лет. В контрольную группу вошли 25 сверстниц без нарушений менструальной функции. Частота случаев рецидивов АМКПП в I группе составила 20,4\%, во II группе - 28,5\%.

Ультразвуковое и допплерометрическое исследование выполнялось при помощи ультразвукового сканера "Siemens" (Германия), с использованием трансабдоминального датчика (3,5 МГц) и трансвагинального датчика (6,5-7 МГц) у подростков, живущих половой жизнью.

Состояния кровотока в маточных и спиральных артериях проводилась с помощью допплерометрического исследования. Рассчитывали индексы сосудистого сопротивления в обеих маточных и спиральных артериях, индекс резистентности (IR), пульсационный индекс (PI), систоло-диастолическое соотношение (S/D).

Результаты: Проведенное исследование выявило гемодинамические изменения кровотока у девочек с АМКПП. В связи с чем, описанные изменения параметров кровотока в а. uterinae и a. radialis, могут служить дополнительным диагностическим критерием определения риска развития маточных кровотечений в пубертатном периоде.

Выводы: На основании проведенного исследования выявлены ультразвуковые и допплерометрические особенности со стороны органов малого таза у девочек-подростков с АМКПП, которые характеризовались увеличением размеров матки, неоднородной эхоструктурой эндометрия, увеличением размеров яичников, повышением систолической и диастолической скоростей кровотока, а также индексов сосудистого сопротивления в а. uterinae и a. radialis.

ключевые слова: пубертатный период, аномальные маточные кровотечения, особенности кровотока

\section{Introduction}

Protection of reproductive health is one of the priority areas for the development of healthcare in Ukraine [1]. Menstrual dysfunction (MD) ranks high among gynecological diseases in adolescent girls, including the disorders associated with abnormal uterine bleeding of puberty (AUBP), which often leads to pathological conditions of menstrual and reproductive function in future $[2,4]$.

The frequency of detection of AUBP in the structure of adolescent gynecological diseases is $10-37.5 \%$, and is the reason of visiting a gynecologist in 30-40\% [3, 6]. Clinical manifestations of AUBP in the form of bleeding from the genital tract are accompanied by weakness, dizziness, posthemorrhagic anemia, resulting in reduced ability to work, psychological stress and depression, the impossibility to live a productive life. Subsequently, women with AUBP have a history of serious obstetric and perinatal complications $[1,4,5,6]$. Given the incidence, tendency to relapse, the impact on the reproductive health of a future woman, the problem of AUBP remains relevant and socially significant.

In the course of MD development, the main role belongs to changes in the functional state of the hypothalamic-pituitarygonadal complex. Moreover, blood supply to the pelvic organs also plays an important role [7].

Research methods are essential in the assessment of the condition of the internal genital organs of adolescent girls with AUBP. Thus, the methods of choice in pediatric and adolescent gynecology are ultrasound and Doppler studies, which require minimal preparation and do not cause psychological discomfort in patients. Currently, issues of the peculiarities of uterine blood flow in adolescent girls with AUBP remain unexplored [4].

The purpose of this study was to evaluate the ultrasound characteristics of the pelvic organs and the features of uterine blood flow in adolescents with abnormal uterine bleeding of puberty.

\section{Material and methods}

The study was carried out at the Department of Obstetrics, Gynecology and Pediatric Gynecology of Kharkiv National Medical University. The study involved examination of 93 adolescents with AUBP aged 11 to 18 years (mean age was $14.5 \pm 3.5$ years). Patients with AUBP were divided into 2 clinical groups: Group I consisted of 44 11-14-year-old patients, Group II of 49 15-17-yearold adolescents. Such a division into the groups was carried out due to the fact that, depending on the age of the patient with AUBP, there were marked clinical and laboratory manifestations associated with the menstrual age, duration and frequency of bleeding recurrence. The control group included 25 peers without menstrual dysfunction. The control group was not divided by age, since menstruating girls aged 13-14 and 15-17 years were not found to have significant differences in blood flow in the uterine and ovarian arteries, which is consistent with the literature $[1,5]$.

The incidence of AUBP recurrence was $20.4 \%$ in Group I and $28.6 \%$ in Group II.

All the patients underwent a comprehensive clinical and laboratory examination. Ultrasound and Doppler study were performed using a Siemens ultrasound scanner (Germany) using a transabdominal transducer $(3.5 \mathrm{MHz})$ and a transvaginal transducer (6.5-7 MHz) in sexually active adolescents.

Ultrasound examination of the pelvic organs assessed the state of the structure of the endo- and myometrium of the uterus, their relationship and uniformity. Identification of focal changes in the endometrium was accompanied with the description of their sizes. Moreover, ovarian sizes were determined and follicular apparatus was evaluated $[7,8]$.

Characterization of the state of blood flow in the uterine and spiral arteries was carried out using a Doppler study at the time of examination of patients in the hospital. The study in patients of the 
control group was carried out in the first phase of the menstrual cycle on the 5th-7th day from the beginning of menstruation.

The uterine artery was visualized in the longitudinal plane at the level of transition of the cervix into the body. First, a longitudinal image of the cervix was obtained, and then the sensor was displaced to the lateral side until the vascular bundle of the uterus began to be clearly visualized at the level of the supravaginal part of the cervix.

The spectrum of blood flow velocity curves on the medial side from the bifurcation of the common iliac artery, typical for the vasculature with low resistance, was recorded in the form of a two-phase curve with low pulsation and high diastolic velocities [7]. Blood flow in spiral arteries was recorded in the area of their anatomical projection, in close proximity to the basal lamina of the endometrium [4].

When conducting a Doppler study, vascular resistance indices in both uterine and spiral arteries, resistance index (IR), pulsation index (PI), systolic-diastolic ratio (S/D) were calculated.

Statistical processing was performed using the Statistica for Windows version 6.1 general-purpose data processing software package.

Prior to the study, the protocol was presented at a meeting of the Ethics Committee of Kharkiv National Medical University. The study was started after approval of the protocol. According to the recommendations, the patients and their parents were informed about the purpose of the study, research methods, potential benefits and risks, as well as possible discomfort during the diagnosis. It was also explained that the decision on the participation or non-participation of the patient in this study at any stage of its implementation would not affect further management of the patient.

\section{Results and their discussion}

Ultrasound scan of the pelvic organs showed that the sizes of the uterus and ovaries in Groups I and II patients significantly exceeded the age parameters of girls in the control group (Table 1). Most of the examined patients of both groups were found to have endometrial hyperplasia. The endometrium in adolescent girls with AUBP was characterized by a heterogeneous echostructure. In $29(65.9 \%)$ adolescent girls of both groups, multiple hypo- and anechogenic inclusions were visualized secondary to heterogeneous structure of the endometrium.

Ovarian ultrasound revealed a multifollicular structure of the ovaries in $65 \%$ of patients in both groups. Retention formations of the ovaries were determined in $20 \%$ of Group I and in $35 \%$ of Group II patients $(\mathrm{p}<0.05)$. Table 1 presents the average size of the ovaries (right and left) in patients of the clinical groups.

Blood supply to the endometrium is known to be carried out by branches of the uterine arteries [6,7]. Radial arteries pass through the myometrium, and are then formed in the direct and spiral branches near the uterine cavity. Direct branches, which are called basal arteries, directly supply the basal layer of the endometrium. It is these vessels that supply the endometrium with blood. The function of the spiral arteries is the nutrition of the functional layer of the endometrium [2].

For a more accurate assessment of uterine hemodynamics and to avoid diagnostic errors, a Doppler study was performed in both uterine arteries [6]. Since the digital data of blood flow in the uterine arteries on the left and on the right did not have significant statistical differences, we presented the averaged parameters of this measurement (Table 2).

Table 1 Ultrasound characteristics of the pelvic organs of patients with abnormal uterine bleeding of puberty

\begin{tabular}{|c|c|c|c|c|}
\hline \multirow{2}{*}{\multicolumn{2}{|c|}{ Pelvic organs }} & \multicolumn{3}{|c|}{ Clinical groups } \\
\hline & & Group 1 & Group 2 & Control group \\
\hline \multicolumn{2}{|c|}{ Length of the uterus, $\mathrm{mm}$} & $57.5 \pm 0.5$ & $75.5 \pm 0.5$ & $51.5 \pm 1.5$ \\
\hline \multicolumn{2}{|c|}{ M-echo, mm } & $8.5 \pm 1.5$ & $12.0 \pm 1.5$ & $5.0 \pm 0.5$ \\
\hline \multirow[t]{2}{*}{ Ovaries } & Length, mm & $38.6 \pm 1.4$ & $42.4 \pm 2.4$ & $27.6 \pm 0.4$ \\
\hline & Width $\mathrm{mm}$ & $30.5 \pm 1.5$ & $32.5 \pm 1.5$ & $19.5 \pm 1.5$ \\
\hline
\end{tabular}

Note: * significance of differences compared with the control group, $\mathrm{p}<0.05$.

Table 2 Dopplerometric characterization of patients with abnormal uterine bleeding of puberty

\begin{tabular}{|c|c|c|c|c|}
\hline \multicolumn{2}{|c|}{ Ultrasound findings } & \multirow{2}{*}{$\begin{array}{c}\text { Group } 1 \\
29.9 \pm 0.3^{*} \\
\end{array}$} & \multirow{2}{*}{$\begin{array}{c}\text { Group } 2 \\
22.2 \pm 0.2^{*} \\
\end{array}$} & \multirow{2}{*}{\begin{tabular}{|c|} 
Control group \\
$18.7 \pm 0.4$ \\
\end{tabular}} \\
\hline Arteria uterinae & Vs, $\mathrm{cm} / \mathrm{s}$ & & & \\
\hline & $\mathrm{Vd}, \mathrm{cm} / \mathrm{s}$ & $9.4 \pm 0.5^{*}$ & $6.5 \pm 0.2^{*}$ & $5.7 \pm 0.1$ \\
\hline & Vcp & $19.65 \pm 0.4^{*}$ & $14.35 \pm 0.3^{*}$ & $8.9 \pm 0.26$ \\
\hline & S/D & $3.18 \pm 0.3$ & $3.41 \pm 0.3^{*}$ & $3.28 \pm 0.3$ \\
\hline & PI & $1.41 \pm 0.26$ & $1.09 \pm 0.06^{*}$ & $1.46 \pm 0.06$ \\
\hline & RI & $0.68 \pm 0.01$ & $0.70 \pm 0.01 *$ & $0.45 \pm 0.01$ \\
\hline \multirow[t]{6}{*}{ Arteria radialis } & Vs, cm/c & $8.87 \pm 0.22^{*}$ & $7.92 \pm 0.28$ & $6.02 \pm 0.28$ \\
\hline & $\mathrm{Vd}, \mathrm{cm} / \mathrm{s}$ & $2.45 \pm 0.08^{*}$ & $2.22 \pm 0.10$ & $1.89 \pm 0.10$ \\
\hline & Vav, $\mathrm{cm} / \mathrm{s}$ & $5.66 \pm 0.01^{*}$ & $5.07 \pm 0.17$ & $3.16 \pm 0.17$ \\
\hline & S/D & $3.62 \pm 0.08$ & $3.56 \pm 0.14$ & $2.92 \pm 0.14$ \\
\hline & PI & $1.13 \pm 0.04^{*}$ & $1.12 \pm 0.08$ & $1.31 \pm 0.08$ \\
\hline & RI & $0.72 \pm 0.01$ & $0.72 \pm 0.02$ & $0.68 \pm 0.02$ \\
\hline
\end{tabular}

Note: * - significance of differences compared with the control group, $\mathrm{p}<0.05$. 
In order to better understand the processes leading to the development of AUBP, as well as changes occurring in the uterus, we conducted a comparative study of the state of the endometrium and blood flow in the uterine arteries of patients of the main and control groups.

Blood flow in the uterine and ovarian arteries in menstruating girls of the control group without menstrual dysfunction did not significantly differ from the literature data [9].

All the girls with AUBP had a hypervascular type of blood supply. There was a tendency to an increase in systolic, diastolic and average blood flow velocities with an increase in PI and RI, S / D in a. uterinae and a. radialis, compared with the control group (Table 1).

Clinical Groups I and II were found to have an increase in systolic and diastolic blood flow velocity in the uterine artery by 1.6-1.2 times, respectively. IR in a. uterinae also exceeded the data of the control group in Groups I and II by 1.5 times.

Systolic velocity in a. radialis in girls with AUBP in Groups I and II also exceeded the value in the control group by 1.5-1.3 times, the diastolic rate by 1.3-1.2 times, respectively. IR in a. radialis exceeded the data of the control group in Groups I and II by 1.1 times.

In girls with AUBP there was an increase in blood flow in a. uterinae and a. radialis, which was probably associated with an increase in the number of estrogen receptors and an increase in the action of estradiol [7]. The level of the latter especially increases in the premenstrual period and in endometrial hyperplasia.

Hypervascularized type of blood supply to the uterus in AUBP associated with an increase in blood flow velocities in a. uterinae, a. radialis in girls in Groups I and II may explain one of the mechanisms of hemorrhage.

The study revealed hemodynamic changes in blood flow in girls with AUBP. In this connection, the described changes in blood flow parameters in a. uterinae and a. radialis, can serve as an additional diagnostic criterion for determining the risk of uterine bleeding in the pubertal period.

\section{Conclusion}

The study showed ultrasound and Dopplerometric features of the pelvic organs in adolescent girls with AUBP, characterized by an increase in the size of the uterus, an inhomogeneous echostructure of the endometrium, an increase in the size of the ovaries, an increase in systolic and diastolic blood flow velocities, as well as vascular resistance indices in a. uterinae and a. radialis.

Disclosures: There is no conflict of interest for all authors.

\section{References}

1. Tuchkina I.A., Zobina Yu.L., Lossovaya M.A., Tuchkina M.Yu. Patologiya pubertata i realizatsiya reproduktivnogo potentsiala zhenskogo organizma: kliniko-terapevticheskie paralleli (Pathology of puberty and the realization of the reproductive potential of the female body: clinical and therapeutic parallels) [in Russian]. Zdorov'e zhenshchiny. 2010; 3(49):175-178.

2. Tuchkina I. O. Etapna reabilitacija pidlitkiv z ginekologichnymy zahvorjuvannjamy ta junyh vagitnyh z ekstragenital'noju patologijeju. Harkiv. derzh. med. un-t. 2007; 348.

3. Tuchkina I.A., Gilenko Zh.O. Neotlozhnaja pomoshh' pri pubertatnyh matochnyh krovotechenijah, oslozhnjonnyh postgemorragicheskoj anemiej na fone jekstragenital'noj patologii (Emergency care for pubertal uterine bleeding complicated by posthemorrhagic anemia on the background of extragenital pathology) [in Russian]. Vestnik KazNMU. 2014; 4:26-29.

4. Uvarova E. V. Anomal'nye matochnye krovotechenija (Abnormal uterine bleeding) [in Russian]. Reproduktivnoe zdorov'e detej i podrostkov. 2013; 3:73-88.

5. Levenec S.A., Nachetova T.A., Vvedenskaja T.S. Prognosticheskaja znachimost' narushenij krovosnabzhenija matki i jaichnikov v vozniknovenii vtorichnoj amenorei u devochek-podrostkov (Prognostic significance of uterine and ovarian blood supply disorders in the occurrence of secondary amenorrhea in adolescent girls) [in Russian]. Original'nye issledovanija. 2012.; 5(91).

6. Dynnik V. A. Narushenija dinamicheskogo ravnovesija v sisteme svertyvanija krovi pri anomal'nyh matochnyh krovotechenijah pubertatnogo perioda (Violations of dynamic equilibrium in the blood coagulation system with abnormal uterine bleeding of the puberty) [in Russian]. Nauchnye vedomosti Belgorod. gos. un-ta. Medicina. Farmacija. 2015; 32(22):73-80.

7. Strizhakov A. N., Bunin A. T., Medvedev M. V.. Ul'trazvukovaja diagnostika v akusherskoj klinike (Ultrasound diagnostics in the obstetric clinic) [in Russian]. Medicina. 2010; 237.

8. Bogdanova E. A. Prakticheskaja ginekologija molodyh (Practical gynecology of the young) [in Russian]. Medicinskaja kniga. $2011 ; 256$.

How to cite this article: Irina Tuchkina, Lyudmila Vygovskaya, Anastasia Novikova. Features of uterine blood flow in adolescents with abnormal uterine bleeding of puberty. J Clin Med Kaz. 2019; 4(54):21-24 